\title{
A Socio-pragmatic Analysis of Selected Covid-19-related Utterances
}

\author{
Acheoah John Emike ${ }^{1}$, Garba Azika Jega ${ }^{2}$ and Okoh Gloria Onyemariechi ${ }^{2}$ \\ ${ }^{1}$ Department of European Languages, Federal University Birnin-Kebbi, Kebbi State, Nigeria.
}

${ }^{2}$ Okoh Gloria Onyemariechi, Department of English, Waziri Umar Federal Polytechnic, Birnin-Kebbi, Kebbi State, Nigeria.

Email: actualemike@gmail.com

\begin{abstract}
This study is a socio-pragmatic analysis of selected utterances of interlocutors whose discourse subject is "Covid-19". In using language, it is not enough to be grammatical; language use should be underpinned by contextual nuances because this is a good way of using language as actions that produce results or effects. Therefore, the analysis of the selected linguistic structures in this study is an investigation of linguistic competence demonstrated through lexical choices and speech act sequencing. The approach explored in the study is discursive and integrative; for example, instead of strictly listing the speech acts performed in each utterance, they are mentioned in terms of how they impinge on the on-going interaction. The study underscores who says "what?", "how?" and "why?". Although this study is mainly hinged on the Pragma-crafting Theory, Bach and Harnish's [1] speech act taxonomy is explored in the classification of the speech acts performed in the utterances. On the whole, the study concludes that the socio-pragmatic use of language is underpinned by the psychological and situational context(s), and produces expected results due to speaker-hearer shared knowledge.
\end{abstract}

KEYWORDS: Sociolinguistics, pragmatics, the Pragma-crafting Theory, speech act theory, Covid-19

A Socio-pragmatic Analysis of Selected Covid-19-related Utterances

\section{Background to the Study}

Many Nigerians do not comply with the non-pharmaceutical measures recommended by health officials to curb Covid-19. This is largely because many Nigerians do not believe the virus exists in the country, if at all it exists in other climes of the world. Efforts made by various governments and their agencies, to sensitize the populace to comply with Covid-19-related safety protocol yield insignificant results. This status-quo informed our interest in analyzing natural (real life) communication of any Covid-19related discourse. Thus, the recorded sample of conversation, presented for analysis in this study, was selected mainly because of its socio-pragmatic potentials.

\section{Introduction}

This study investigates the dynamics of language as its instrumentality is "unleashed" to solve a societal problem: the Covid-19 pandemic. According to David J. Cennimo [2], “... the WHO declared Covid-19 outbreak a global health emergency ${ }^{1}$. On March 11 2020, the WHO declared COVID-19 a global pandemic, its first such designation since declaring H1N1 influenza a pandemic in 2009." The fallouts of this declaration are series of actions taken by the governments of different countries to combat the surge of the virus. The text presented in this study captures how such actions of governments impinge on the language of the interlocutors.

\section{The Socio-pragmatics of Language Use}

Indeed, the socio-pragmatics of language use is essentially driven by speaker-hearer roles in a communication activity. The dimensions of human communication accentuate the difference between man (generic) and animals. To encode and decode utterances, human beings hinge on world knowledge. "Meaning" is an indispensable component of human communication (written and spoken discourses). In transacting meaning, the participants deploy their linguistic competence and extra-linguistic knowledge. Bara [3] notes that "human beings, unique among animals, possess a basic communicative competence that sustains both the linguistic and extralinguistic way of expressing it."

The selected linguistic structures in this study (the text) explain the socio-pragmatic motivations for language use by depicting the bond between "meaning" and "discourse/ communication". Charles Ogbulogo, cited in Acheoah [4] opines that "communication ... is the exchange or relay of information, messages, attitudes, feelings or values from one person to another. This is done mainly by the use of language. It is often expressed that language is a system, which uses a set of symbols agreed upon by a group. These symbols can be spoken or written, expressed as gestures or drawings."

In using language to make reference(s) to Covid-19, the Nigerian governments and their agents, as well as the populace, are aware of the various ideas conveyed - the referents picked out by language from the world/universe of discourse. According to Ogbulogo, cited in Acheoah [4], "reference relates to things, people and events in the world. It is the object or entity to which a linguistic expression relates. Thus, the referent of the word "boy" 
is a human being called boy." Language is deployed as action when it is used to encode and decode written and spoken texts.

The Greek pragma from which pragmatics is formed means "deed/action". Pragmatics is attributed to Charles Morris, who attempted outlining the general shape of a science of signs (semiotics). Pragmatics emerged as a reaction against formalism (conventions/norms of language). Through pragmatics, language use is explained; by relying heavily on specific contexts and social phenomena (state-of-affairs). The assumption is that significant functional explanations can be given for facts about language as it is used to messages, such as those of Covid-19. The meaning of an utterance, rather than its grammaticalness, is the major concern of pragmatics. A fascinating field of language study, pragmatics explains how language users - such as the various governments and their agents who transmit Covid-19 messages, as well as the decoders of such messages (who express their views on such messages) - process language in natural communication. The early and contemporary scholars of this field of linguistics (pragmatics), are referred to as "language philosophers". Pragmatics investigates the "who", "where", "how", "when" and "why" of linguistic and extralinguistic elements of communication. These "wh-" elements explain the relationship between pragmatics and sociolinguistics the latter and the former are "micro" and "macro" underpinnings of language use respectively.

\section{Covid-19}

According to David J. Cennimo [2], "Coronavirus 2019 (Covid-19) is defined as illness caused by a novel coronavirus now called severe acute respiratory syndrome corona virus 2 (SARS-Co V-2; formerly called 2019-n(Co V), which was first identified amid an outbreak of respiratory illness cases in Wuhan city, Hubei Province, China. It was initially reported to the WHO on December 31, 2019 ..." A lot of useful information abound in different medical publications in terms of the transmission, precautions and symptoms of the disease. Consider the following elaborate submission taken from the UNICEF WCARD [5]:

The virus is transmitted through direct contact with respiratory droplets of an infected person (generated through coughing and sneezing), and touching surfaces contaminated with the virus. The Covid-19 virus may survive on surfaces for several hours, but simple disinfectants can kill it ...

Symptoms can include fever, cough and shortness of breath. In more severe cases, infection can cause pneumonia or breathing difficulties. More rarely, the disease can be fatal ... Here, are four precautions you and your family can take to avoid infection:

- Wash your hands frequently using soap and water or an alcohol-based hand rub;
- Cover mouth and nose with flexed elbow or tissue when coughing or sneezing. Dispose of used tissue immediately;

- Avoid close contact with anyone who has cold or flu-like symptoms;

- Seek medical care early if you or your child has a fever, cough or difficulty breathing.

\section{Theoretical Framework}

This study explores two theoretical frameworks: Acheoah's [6] the Pragma-crafting Theory as well as Bach and Harnish's [1] speech act theory:

\subsection{The Pragma-crafting Theory}

The Pragma-crafting Theory explains the systematic and context-driven nature of using and interpreting language via crafting; verbal and non-verbal elements of communication are interpreted from smaller structures to larger ones. Within the framework of the theory, "P-crafting" is a super-ordinate pragmatic act which produces linguistic and extra-linguistic elements of communication. At different stages of a communicative event, there is a candidate for meaning (inference). The P-crafting features (inference features) which the participants explore include indexicals (INDXLs), Shared Macro-knowledge (SMK), Shared Contextual Knowledge (SCK), Shared Knowledge of Emergent Context (SKEC), Geoimplicatures (GIs), Linguistic Implicatures (LIs), Behavioural Implicatures (BIs), Contextual Presuppositions (CPs), Pragmadeviants (PDs), Object Referred (OR) and Operative Language $(\mathrm{OL})$. We shall explain a few of these concepts that are crucial to this study. See Acheoah [6] for elaborate perspectives on the theory, including the diagram. However, as we proceed with the analysis, other relevant concepts in the theory will be explored, thus making their meanings clear.

i. Setting: This is the physical context of the communicative event in both immediate and remote (referential) sense.

ii. Theme: This is the message conveyed in/by Text.

iii. Sociolinguistic Variables: They are meanings conveyed by age, cultural background, social status, race, gender, relationships, etc.

iv. Psychological Acts: These are the different emotions expressed through linguistic and extra-linguistic acts.

v. Inference: Inference-making has to do with making logical deductions from available linguistic and extra-linguistic components of Text.

vi. Indexicals: They are grammatical categories that have the potential to establish the relationship between language and context.

vii. Shared Contextual Knowledge: This refers to available pieces 
of information available to participants of the on-going discourse for effective communication.

viii. Emergent Context: It is any emergent situation in an ongoing communicative event. It redirects the performance and interpretation of subsequent linguistic, extra-linguistic and psychological acts. An emergent context becomes Shared Knowledge of Emergent Context when it translates into common knowledge of the participants of discourse.

ix. Geoimplicature: Coined from "geographical" and "implicature", the term "Geoimplicature" refers to verbal and non-verbal practices that are restricted to race and geographical (physical) boundary; they are not universal human behaviour.

x. Linguistic Implicature: It is any meaning implied through language.

xi. Behavioural Implicature: It is any meaning conveyed by extra-linguistic and psychological acts.

xii. Contextual Presupposition: This is a product of shared contextual knowledge.

xiii. Background Assumptions: In an on-going communication, participants deduce meanings from verbal and non-verbal data. Such meanings are referred to as Background Assumptions (BAs).

xiv. Pragmadeviants: They are deviant expressions used by participants of discourse, as illocutionary strategies.

xv. Interactive Participant: This is an interlocutory participant who performs linguistic, extra-linguistic and psychological acts, as communicative contributions that do not only impinge on the interpretive process, but also determine or generate sequel (perlocutionary act).

xvi. Non-interactive Participant: A non-interactive participant does not participate in an on-going communicative event, but is intentionally or accidentally present in the physical context.

\subsection{Bach and Harnish's Speech Act Theory}

Kent Bach and Robert Harnish's [1] speech act theory is immersed in speakers' intentions and inference-making. Their argument is that hearers have to understand illocutionary acts performed in speakers' utterances. Their terminology, "Speech Act Schemata" (SAS), refers to an inevitable process in inferencemaking, facilitated by speaker-hearer Mutual Contextual Beliefs (MCBFs).

Bach and Harnish's speech act categories are elaborate: Assertives, Informatives, Confirmatives, Concessives, Ascriptives, Retractives, Assentives, Dissentives, Disputatives, Responsives, Suggestives, Suppositives, Descriptives, Directives and Advisories (ibid. pp. 42-46).
They explain that, "Assertives are characterized by S's expression of belief that the hearer $(\mathrm{H})$ also believes that $\mathrm{P}$ ”.

Informatives are speech acts in which $\mathrm{S}$ (Speaker) expresses the belief that $\mathrm{P}$ " and "the intention that $\mathrm{H}$ form the belief that $\mathrm{P}$ ".

In Descriptives, $\mathrm{S}$ declares that a particular quality is possessed by a person, place or thing. That is, $\mathrm{S}$ expresses "the belief that $\mathrm{O}$ is F" and "the intention that $\mathrm{H}$ believes that $\mathrm{O}$ is $\mathrm{F}$ ".

Directives are speech acts which expresses the speaker's attitude towards a future action by the hearer $(\mathrm{H})$ and the speaker's intention or desire that $\mathrm{H}$ consider his utterances as reason to act (A). Six categories of illocutionary acts are listed under this category: Responsives, Questions, Requirements, Prohibitives, Permissives and Advisories.

Questions are "special cases of requests in that what is requested is that the hearer provides the speaker with certain information" (p. 48). A speech act is a question if S expresses "the desire that $\mathrm{H}$ tells $\mathrm{S}$ whether or not $\mathrm{P}$ " and "intention that $\mathrm{H}$ tells $\mathrm{S}$ whether or not P because of S's desire” (p. 47).

Advisories are speech acts in which the speaker expresses the belief that "there is (sufficient) reason for $\mathrm{H}$ to A," and "the intention that $\mathrm{H}$ takes $\mathrm{S}$ 's belief as (sufficient) reason for him to A".

The third major category of speech acts established by Bach and Harnish [1] are Commissives - acts involving the undertaking of an obligation or proposal to undertake an obligation. Two major types of this category are established: Promises and Offers. $\mathrm{S}$ promises $\mathrm{H}$ to $\mathrm{A}$ if $\mathrm{S}$ expresses "the belief that his utterance obligates him to A", "the intention to A", and the intention that $\mathrm{H}$ believes that $\mathrm{S}$ 's utterance obligates $\mathrm{S}$ to $\mathrm{A}$, and that $\mathrm{S}$ intends to A'.

For more insight on the speech act taxonomy and the verbs that denote them, see Bach and Harnish (ibid.).

\section{Presentation and Analysis of Data}

This section presents the data, and analyzes them.

\subsection{Presentation of Data}

The utterances to be analyzed in this study are gathered from Covid-19-related conversations of two discussants, recorded in a market setting on July $25^{\text {th }}, 2020$. These utterances are first presented as speaker-hearer conversational exchange, before they are then divided into twenty three utterances (henceforth U.1 U.23) for easy analysis.

Speaker: There is Coronavirus in town. Stay safe.

Hearer: I beg leave that thing. For this Naija, if I miss how will they find me? Person fit trace spirit? You know how many corners I have entered today? They will be tired. The 
thing wen dey do person pass Coro. I am wearing this mask because man must wak. It is compulsory in my office where I will be going very soon. Do you believe Naija Coro? Show me the people ... locking us at home as if ... Na big man sickness. In fact, the thing no dey catch black man.

Speaker: Coronavirus is real oh! Can't you see me panick-buying?

Hearer: When last did you see Richard?

Speaker: Ehmmm ... I have not seen him this week. He is a frontliner.

Hearer: Continue. Continue. Medical jargons.

Speaker: Ignorance. Many of you are not law-abiding. Stay safe. Save lives. Beware of community transmission. God help the task force.

Hearer: The Wuhan virus is real in Wuhan.

Consider the utterances generated:

U.1: There is Coronavirus in town. Stay safe.

U.2: I beg leave that thing.

U.3 For this Naija, if I miss how will they find me?

U.4 Person fit trace spirit?

U.5 You know how many corners I have entered today?

U.6 They will be tired.

U.7 The thing wen dey do person pass Coro.

U.8 I am wearing this mask because man must wak.

U.9 It is compulsory in my office where I will be going very soon

U.10 Do you believe Naija Coro?

U.11 Show me the people.

U.12 ... locking us at home as if ...

U.13 Na big man sickness.

U.14 In fact, the thing no dey catch black man.

U.15 Coronavirus is real oh!

U.16 Can't you see me panick-buying?

U.17 When last did you see Richard?

U.18 Ehmmm ... I have not seen him this week.

U.19 He is a frontliner.

U.20 Continue. Continue. Medical jargons.

U.21 Ignorance. Many of you are not law-abiding. Stay safe. Save lives. Beware of community transmission.
U.22 God help the task force.

U.23 The Wuhan virus is real in Wuhan.

\subsection{Analysis of Data}

Integrative analyses are presented in this section.

U.1 contains varied speech acts: Informative, Directive and Advisory; the encoder brings to his interlocutor, the news of an outbreak of Coronavirus, and in an implied manner, advises this interlocutor to be safe, in terms of practicing the necessary safety guidelines given by health experts. U.2 is a Dissentive; the speaker's interlocutor agitates, and does not show willingness to obey the Advisory. There is a topic-shift in the sense that $\mathbf{U} . \mathbf{3}$ is not an appropriate response for U.1. Any decoder of U.1 should not be talking about escaping (... if I miss ...). However, the topicshift is informed by the socially realistic phenomena that underpin the conversation. The encoder of $\mathbf{U . 2}$ expects the utterance to be understood by his interlocutor who already knows that governments' agencies, institutions or departments are engaged in tracing and tracking victims of Coronavirus. Indeed, the encoder of

U.2 thinks the government is attempting to achieve the impossible; victims of Covid-19 move from one place to another very rapidly as they seek their daily bread and attend to other numerous appointments. Different factors make tracking and tracing of suspected victims of Covid-19, extremely difficult: Nigerians live in destinations with vague addresses; people change appearances when they change clothes for various "outings".

The thematic underpinnings of $\mathbf{U . 7}$ - U.9 are clear: people have problems, needs and worries that transcend their concern about Coronavirus. In Western Nigeria, when the short form of "Coronavirus" ("Coro") is used in conversations, the reason is sometimes to make mockery of the disease, and those who propagate it. From the responses of H (U.2 - U.14), it can be inferred that the participants in this speech community believe that "hunger virus" (as many of them put it), is worse than Coronavirus. These people think that the lockdowns imposed by governments at federal and state levels, as well as the safety measures recommended by health officials, are too stiff for them to comply with. They want to be out on the streets to earn a living for themselves and their families. They do not even think the virus is real - as implied (conversational implicatures) in the Ascriptive (U.10) and Dissentive (U.11).

U.11 may be regarded as a biblical allusion, because it is reminiscent of Judas Iscariot (a Bible character); by requesting to see true victims of Covid-19, the unbelieving Nigerians can be compared to Judas Iscariot who wanted to feel the palms of Jesus Christ before believing His resurrection. Extending the underpinnings in the immediate setting of the text (market), and situating it within the larger context (Nigeria), we posit that many 
Nigerians doubt the cases of Covid-19 reported in the media; cases of people hospitalized or put in isolation centres. The encoder of U.22 understands that it will be difficult for the government to combat the disease if the mindset of Nigerians about the virus is not changed. Nigerians believed the outbreak of other diseases in the country: Laser Fever, Polio, Cholera, etc. The social media worsen the situation of non-compliance to Covid-19 protocol, as they spread fake news about the virus.

The encoder of U.12 explores Shared Macro Knowledge; the knowledge that since freedom of movement is a fundamental human right, the imposition of lockdowns is an infringement of such rights. One cannot deny the hardship that is attendant to lockdowns. However, to cushion the effects of such lockdowns, particularly on those who depend on daily income, the various governments gave palliatives to the needy, and also eased the lockdowns in phases. Like lockdowns, quarantine or self-isolation helps control the spread of the virus (U.21). U.13 is an Assertive which reveals that misconception is inimical to the success of governments' efforts to fight the pandemic. It is the duty of a responsible government to protect its citizens. The utterance "Na big man sickness" is a product of shared knowledge; the encoder, like other Nigerians, is aware of the lifestyle of the elite who travel to different parts of the world, thereby importing the virus into the country. In a television interview, a discussant said "wealthy Nigerians take their breakfast in China, and lunch in Paris same day." Even though these wealthy people are also Nigerians like the poor masses, the encoder of $\mathbf{U . 1 4}$ thinks real Nigerians are the poor ones whose immune systems have been considerably improved by daily hardship.

Through language use, we can read into the mindset of the interlocutors. We can say that the encoder of the expressions: "frontliner" (public workers who are at the forefront of the battle against the virus, particularly health workers) as in U.19; and "panick-buying" (rushing to buy and store things that will sustain someone during lockdowns) as in U.16, is favourably disposed towards the governments' efforts to curb the disease. This encoder is at pace with the scheme of things as language is being used by the media to sensitize society towards combating Cocid-19.

Besides "frontliner" and "panick-buying", other expressions were brought to limelight when the Coronavirus struck. A notable example is "new normal". The emergence of words to cope with societal issues is essentially part of the thrust of sociolinguistic research (language and society).

\section{Discussion}

The use of language in $\mathbf{U . 1}$ - U.23 is a demonstration of the fascinating roles of speech acts in the transmission and interpretation of message in any communicative event. For example, while the government-supportive encoder (the Speaker in the text) uses Informative to achieve intended illocutionary goal, the decoder
- just like any other non-government-supportive Nigerian uses Ascriptives and Dissentives to reject the Covid-19-related messages. We postulate that four categories of people are depicted in the text: the government; Nigerians (extratext non-participants); the speaker (pro-government intratext participant); and the hearer (anti-government intratext participant). We do not use "anti" in the denotative sense. It is simply preferred in this study, for analytical purpose. The intratext pro-government participant explores sociopragmatic principles of language to inform, persuade, convince, mobilize and advise the intratext anti-government participant and by extention, the extratext non-participants. On the other hand, the intratext anti-government participant explores the sociopragmatic principles of language use (invoking societal norms such as fundamental human right of freedom of movement) and using appropriate speech acts (dissuading, agitating and rejecting). Thus, the speech acts in the discourse are produced to specifically address the on-going issues. David Harrah, cited in Savas L. T. [7] opines that "speech acts seem to be focused and directed. They are intended as coming from the agent and going to the receivers or audience. They are intended to have a certain point, and they are intended to be construed as having a certain point ${ }^{2}$."

A critical review of the two theories explored in this study shows that the user of language in a communication situation, tries to make the receiver of a piece of information believe what is said about x (an infinite reference/referent). William P. Austin, cited in Savas L. T. [7], posits that "communication theories differ as to the feature of communication they pick as crucial for meaning. Historically, the emphasis has been on the fact that communication involves an attempt to produce psychological effects on an addressee; get the latter to believe or know something, to act in a certain way, to adopt or modify attitudes, and so on." This submission explains what the various Nigerian governments try to achieve, as they advise and inform (educate) the populace on the subject, Covid-19.

Given the divergent attitudinal dimensions of $\mathrm{S}$ and $\mathrm{H}$ in our analyses, it is obvious that Nigerians have mixed feelings about Covid-19; this situation is essentially a psychological context that underpins the communication. Textual analysis is fascinating and greatly revealing when the psychological nuances direct it.

\section{Conclusion}

This study examines language use in the encoding and decoding of Covid-19-related discourse in the micro context (the market), and by extension, the macro context (Nigeria). To understand the messages about the transmission of Covid-19, and the safety measures to be practiced by the Nigerian populace, Nigerians calculate the intentions of the sender(s) of such messages. However, there are extratextual issues which impinge on the addressees' (the populace's) responses (reactions) to the messages. For example, many of them do not trust their governments, 
how much more what such governments or government agents propagate about Covid-19. But this trust-deficit does not mean all Nigerians do not believe in their governments' Covid-19 messages; sociolinguistic variables (as in the Pragma-crafting Theory) can explain the different reactions of the populace ${ }^{3}$. Conclusively, the psychological setting of the text - the mindset of the people in the speech community (Nigeria) - is a determinant of how governments use language to curb Covid-19, and how Nigerians respond to such language use.

Even though the participants (Speaker and Hearer) do not explore all categories of speech acts in Bach and Harnish's [1] speech act taxonomy (and of course they do not have to do so), the ones they explore are germane to their individualistic, divergent illocutionary goals ${ }^{4}$. For example, although the governments' Covid-19-related directives fulfill the felicity conditions for the performance of a directive speech act, $\mathrm{H}$ (like other non-compliant Nigerians) rejects it by exploring a Dissentive ${ }^{5}$.

\section{Notes}

1. This was on January 30, 2020.

2. Stranson, cited in Levinson [9] notes that "understanding is decoding or calculating all that might reasonably be meant by the speaker of the utterance."

3. Factors that can determine how the governments' Covid-19 messages are interpreted by Nigerians include: age, level of education (status), occupational background, etc.

4. "Schemata" is the plural word for "schema". It refers to either (the totality of items of knowledge in the brain) or (the totality of items activated in relation to a particular topic in a communicative process). Each schema denotes items of knowledge that are associated with an object, person, event, action, place, etc." (cited in Adeyemi [9]).

5. When any elected government gives a directive to the citizens of the country that it governs, it is deemed felicitous, because early scholars of speech act theory acknowledge that having legitimate authority to perform a directive speech act, is a felicity condition for the act. Therefore, extra-felicity issues, (not felicity condition), are the reasons why $\mathrm{H}$ and other Nigerians refuse to obey governments' Covid-19related directives or instructions. Cook, cited in Adeyemi [9] gives a list of felicity conditions for different directive acts:
1. The sender believes the action should be done;

2. The receiver has the obligation to do the action;

3. The sender has the right to tell the receiver to do the action (items 3 and 8 are omitted from our source, Adeyemi [9]);

4. The sender refers to an action necessary for a particular goal;

5. The sender refers to an action necessary if the receiver is to avoid unpleasant consequences;

6. The sender refers to an action which will benefit the receiver ...

7. The sender possesses knowledge which the receiver lacks $\cdots$

\section{References}

[1] Bach, K. and Harnish, R. (1979). Linguistic communication and speech acts. Cambridge, Massachusetts: MIT Press, pp. $42-$ 48 .

[2] David, J. Cennimo (2020). MD, FAAP, FACP, AAHIV; Chief Editor: Michael Stuart Bronze, MD, p. 1.

[3] Bara, B. G. (2010). Cognitive pragmatics: The mental processes of communication. Cambridge, MA: MIT Press.

[4] Acheoah, J. E. (2020). Critical perspectives in language and linguistics. Unpublished Manuscript.

[5] UNICEF WCARD, 20 March, 2020, pp. 1, 4-5.

[6] Acheoah, J. E. (2015a). The pragma-crafting theory: A proposed theoretical framework for pragmatic analysis. Journal of English and literature 1(2), 21-32.

[7] Savas, L. T. (1994). Foundations of speech act theory: London: Routlege, pp. 34, 375.

[8] Levinson, S. (1983). Pragmatics. Cambridge: Cambridge University Press.

[9] Adeyemi, O. (2000). Studies in English language. Ibadan: Enicrownfit Publishers, p. 71.

Citation: Acheoah John Emike, Garba Azika Jega and Okoh Gloria Onyemariechi “A Socio-pragmatic Analysis of Selected Covid-19-related Utterances". American Research Journal of English and Literature, Vol 7, no. 1, 2021, pp. 1-6.

Copyright @ 2021 Acheoah John Emike et al., This is an open access article distributed under the Creative Commons Attribution License, which permits unrestricted use, distribution, and reproduction in any medium, provided the original work is properly cited. 